\title{
O Estado brasileiro contemporâneo: liberalização econômica, política e sociedade nos governos FHC e Lula
}

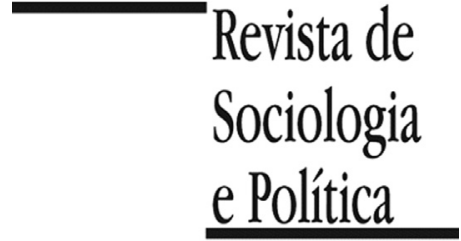

DOI 10.1590/1678-987316246001

\author{
Brasilio Sallum Jr. e Jefferson O. Goulart
}

Resumo

O artigo identifica as características da forma contemporânea do Estado brasileiro - vigente desde 1995 - do ângulo de suas relações com a esfera econômica e de suas políticas frente à desigualdade social. O artigo caracteriza os ideários que orientaram as elites dirigentes, o modo como foi redefinida a política externa brasileira na nova conjuntura internacional posterior à Guerra Fria e as políticas econômicas e de distribuição de renda entre 1995 e 2010. A hipótese central é que há uma nova forma de Estado no Brasil desde 1995 e que as variações entre governos que se sucederam no período são parte da mesma história. O artigo se opõe à caracterização corrente de que os governos FHC e Lula obedeceram a uma diretriz neoliberal. Para isso, procura identificar a diretriz que orientou os dois períodos de governo. Mostra que ela foi liberalizante, sim, mas moderada - no que se refere à redução da intervenção do Estado na economia - mesclando políticas dos ideários neoliberal e liberal-desenvolvimentista. Embora haja bastante continuidade nas políticas do Estado em relação à economia, o artigo mostra que o período Lula teve um papel muito relevante na estabilização do Estado e mesmo da ordem capitalista. Com efeito, a incorporação, à gestão do Estado, de lideranças sindicais, de movimentos sociais e de lideranças de esquerda, somada à ampliação da proteção social aos pobres e miseráveis e a criação de canais de ascensão social para a baixa classe média reforçaram a adesão à ordem capitalista e a estabilidade política, complementando os efeitos estabilizadores já reconhecidos pela literatura das regras democráticas e da estabilidade da moeda.

Palavras-chave: Estado; liberalização; política social; neoliberalismo; desenvolvimento.

Recebido em 21 de Março de 2015. Aceito em 23 de Julho de 2015.

\section{Introdução ${ }^{1}$}

\author{
${ }^{1}$ Agradecemos aos \\ comentários e sugestões dos \\ pareceristas anônimos da \\ Revista de Sociologia e \\ Política.
}

\begin{abstract}
$\mathrm{A}$ $\mathrm{s}$ análises referentes à política brasileira contemporânea têm sido fortemente marcadas tanto pelo exame de aspectos específicos quanto pelo estudo de governos, cujo escopo compreende estudos sobre o processo decisório, as relações entre o Executivo e o Legislativo, o desempenho dos partidos políticos, o papel do Judiciário e assim sucessivamente. Quando se examina a continuidade entre governos, porém, as análises tendem a ser fortemente marcadas por polarizações políticas, quando não abertamente ideológicas. A liberalização econômica, em geral, tem sido o pomo da discórdia. As políticas liberalizantes, nos governos de Fernando Henrique Cardoso, ora têm sido qualificadas como as que permitiram superar a "década perdida" (dos anos 1980) e sintonizar um país "atrasado" ao andamento do "Primeiro Mundo", ora são caracterizadas como destrutivas das conquistas produzidas pela democracia e pela indústria, apoiadas na intervenção e regulação estatais. E, dependendo da posição do analista, os governos de Luiz Inácio Lula da Silva são responsabilizados parcial ou totalmente por aquelas práticas destrutivas (Filgueiras \& Gonçalves 2007; Gonçalves 2010) ou identificados pela reversão daquelas tendências e por promoverem grandes transformações em nosso desenvolvimento (Barbosa \& Dias 2010).
\end{abstract}

Não se tentará aqui negar as diferenças substantivas e mudanças entre esses governos, mesmo entre os que tiveram um mesmo presidente, nem que haja 
${ }^{2}$ A transição do regime político autoritário para a democracia é mais longa e complexa, a rigor tem início na ascensão do general Geisel à presidência e se estende até o processo constituinte e seus desfechos políticos e institucionais, consumando-se com a ascensão do governo de Fernando Henrique Cardoso e a formação de uma nova hegemonia. Sobre o tema, ver Sallum Jr. (1996; 2003), Rocha (2013) e Goulart (2013). continuidade entre eles. Há ambas as coisas na história brasileira contemporânea. Argumentamos, porém, que tais diferenças e continuidades integram uma mesma história, narrativa gestada em um processo longo e conflitivo de transição política (1983-1994) que acabou por levar ao poder uma coalizão sociopolítica que institucionalizou uma nova forma de Estado. Esta passou a regular politicamente a história brasileira contemporânea desde 1995 até os dias de hoje ${ }^{2}$. Essa trajetória foi conformada pelas ambições de dar ao país uma posição de destaque na ordem internacional, manter uma relação democrática com a sociedade e seguir um padrão de Estado moderadamente liberal em suas relações com a economia. Enfatizando as características deste Estado contemporâneo - para além dos sucessivos governos - abre-se espaço para o contraponto com aquele vigente no Brasil entre os anos 1930 e o início da década de 1980.

A política de inserção internacional, a democracia política e a orientação econômica liberal-moderada certamente surgiram anteriormente, mas só se solidificaram em meados dos anos 1990. A forma de Estado que hoje ordena a vida política brasileira tem três pilares: (i) a Constituição democrática de 1988, que estendeu, universalizou e protegeu os direitos de cidadania; (ii) o Plano Real de estabilização monetária, lançado em 1994, e o conjunto de reformas liberais que foram efetivadas no primeiro governo de Fernando Henrique Cardoso; (iii) o ingresso de lideranças sindicais e de movimentos sociais na esfera do Estado, que resultou na intensificação do processo de inclusão da base da pirâmide social.

Embora distantes no tempo, esses pilares políticos estão articulados: a Constituição de 1988 fixou as orientações normativas, as regras e garantias da democracia brasileira, mas não forneceu instrumentos suficientes para assegurar estabilidade econômica ao país antes do Plano Real e das reformas econômicas de Cardoso. Somente aí, com a estabilização da moeda, a maioria da população reconciliou-se com o Estado democrático de direito (Linz \& Stepan 1996). Nesse sentido, a crise de hegemonia que marcou o término do regime autoritário - que combinava obsolescência do modelo de Estado nacional-desenvolvimentista e erosão de sua base política de sustentação finalmente seria superada com a formação de uma nova coalizão sociopolítica e de um novo projeto de sociedade. Ao mesmo tempo, as reformas liberais conseguiam superar - ou, pelo menos, atenuar - as agudas controvérsias patrocinadas pelo empresariado a propósito do suposto "estatismo" da Constituição de 1988. Por fim, a inclusão política das organizações sindicais e de movimentos sociais - fatores determinantes do movimento de democratização dos anos 1980 - lhes tirou a condição de desafiantes do Estado, dando ao conjunto das instituições políticas uma grande estabilidade, além de promover inclusão social em larga escala.

A institucionalização dessa forma contemporânea de Estado foi resultado de disputas acirradas e se conserva com oscilações relevantes na orientação de suas políticas públicas, entendidas em um sentido amplo. Assim, é importante identificar também as balizas político-ideológicas que delimitam a atuação dos diferentes atores coletivos que disputam o poder político e as políticas do Estado. Por fim, esboçaremos os limites da capacidade de transformação dessa forma contemporânea do Estado brasileiro, pois não há forma política que não imponha restrições à dinâmica das transformações sociais.

Ao identificar continuidades, variações no tempo e limites do Estado brasileiro contemporâneo, além das balizas político-ideológicas que moldaram os embates dos seus principais atores sociais e políticos, focalizaremos basicamente as relações do Estado com as esferas econômica e social. Deixaremos de lado as suas características no âmbito político-institucional e as disputas que se 
dão nesta esfera - a luta entre os partidos, as relações entre os poderes de Estado, a representação política e assim por diante. Outro limite que nos impusemos foi o do período considerado, que não ultrapassa 2010, último ano de gestão de Luiz Inácio da Silva, dado que seria difícil incluir na análise o primeiro governo Dilma Rousseff, ainda em curso $^{3}$.

\section{Ideários de superação do nacional-desenvolvimentismo}

\author{
3 Preferimos não fazer aqui \\ uma discussão específica \\ sobre a orientação teórica \\ adotada, pois isso desviaria em \\ demasia de nosso foco de \\ atenção. De qualquer modo, \\ nossa perspectiva pode ser \\ associada, ainda que não haja \\ aqui muita precisão, ao que se \\ tem denominado \\ "institucionalismo histórico". \\ Sobre esta orientação há vasta \\ literatura. Ver, por exemplo, \\ Hall e Taylor (2003). \\ 4 O qualificativo "varguista" \\ reporta-se obviamente à figura \\ e ao legado de Getúlio Vargas. \\ As principais características \\ deste Estado se mantiveram \\ até 1982 e mesmo depois, \\ embora deterioradas. \\ Preferimos essa terminologia à \\ mais usual, "Estado \\ nacional-desenvolvimentista", \\ porque esta se refere apenas à \\ relação Estado-economia, \\ deixando de lado as relações \\ políticas Estado-sociedade, \\ não contemplando seu caráter \\ autoritário e excludente. \\ 5 A respeito do tema da \\ cidadania e de sua trajetória no \\ Brasil, ver especialmente \\ Santos (1979) e Carvalho \\ (2002).
}

\footnotetext{
${ }^{6}$ É sintomático que as duas principais forças políticas que polarizariam a disputa pelo poder a partir de 1994 (o PSDB e o PT) se situassem precisamente nesse campo de oposição ao antigo desenvolvimentismo: o PSDB, por sua crítica aguda ao estatismo e ao padrão
}

Ao longo dos anos 1970-1990, o Brasil experimentou uma crise do modelo de Estado construído depois da Revolução de 1930 e uma longa transição política. Esse processo foi, porém, o aspecto positivo, construtivo, de uma crise de hegemonia que quebrou as crenças centrais e desarticulou as bases sociopolíticas do Estado "varguista"4, orientado para a construção de um sistema industrial nacionalmente integrado (por meio da substituição de importações e com a contribuição decisiva de empresas estatais), socialmente excludente e com participação política limitada e controlada, enfim, uma cidadania regulada ${ }^{5}$.

Sob o impacto da crise da dívida externa, rompeu-se a coalizão política que sustentou o regime político militar-autoritário e o Estado varguista até o início da década de 1980, desencadeando-se um processo de transição política que redefiniu a posição dos vários segmentos sociais no sistema de poder, as relações do poder público com a economia e a relação do Brasil com o exterior. Essa transição compreendeu processos de mudança distintos, embora interconectados, dentre os quais o mais intenso, de início, foi o da democratização. Esta foi sustentada por mobilizações intensas, embora intermitentes, da classe média e do operariado urbanos e de outros movimentos sociais populares que demandavam a extensão ou a instituição de direitos de cidadania e a ampliação de sua participação na renda. Tais movimentos sociais e suas organizações tiveram como expressão político-institucional os partidos políticos que se desdobraram, em 1979, do Movimento Democrático Brasileiro (MDB). Desse impulso democratizante - e de suas "negociações" com as forças sociais e políticas vinculadas à velha ordem política - resultaram um governo civil "de transição" (1985-1989) e uma nova ordenação jurídico-política, a Constituição de 1988, que materializou boa parte das aspirações das forças políticas que sustentavam esse governo. Tal processo de democratização foi marcado, no plano econômico, por oscilações bruscas de crescimento, recessão, estagnação, inflação muito alta permeada por breves reversões, deterioração das finanças públicas e, mais do que tudo, orientações díspares da política do Estado em relação à economia.

Na segunda metade da década de 1980, essa crise de Estado e o movimento de democratização que tentava superá-la condicionaram várias propostas de superação, tanto no que diz respeito às relações entre poder político e economia quanto às articulações entre a sociedade brasileira e seu contexto internacional. Embora o antigo padrão da relação Estado-mercado ainda vigorasse, esse nacional-desenvolvimentismo tinha poucos defensores e se deteriorou. $\mathrm{O}$ antigo desenvolvimentismo resistiu às mudanças, mas de forma localizada e fragmentada, nas múltiplas agências econômicas do Estado e nos segmentos empresariais mais dependentes da proteção estatal. Esse ideário, entretanto, não encontrou defensores no plano político ${ }^{6}$.

Em relação ao velho Estado, as forças sociais e políticas apresentaram basicamente duas alternativas. De um lado, uma opção "liberal" no meio empresarial e em segmentos da tecno-burocracia do Estado. Esse reformismo liberalizante teve duas variantes distintas: uma orientada pelo receituário neoliberal e outra pelo projeto de "integração competitiva". De outra parte, entre os sindicatos de trabalhadores, associações vinculadas à Igreja etc. emergiu uma "alternativa distributiva" ao ideário do antigo desenvolvimentismo. 
populista de dominação política; o PT, por representar uma autêntica ruptura com o antigo modelo, também no plano político, na forma do novo sindicalismo que desafia e rompe com a tutela estatal.

${ }^{7}$ Sobre o esgotamento das políticas de inspiração keynesiana e sua substituição por políticas monetarista $\mathrm{e}$ neoliberais na Inglaterra e na França, consultar Hall (1986).

${ }^{8}$ Adotamos aqui uma perspectiva limitada às relações Estado-economia. Nessa fase de mundialização do capitalismo, as mudanças ocorridas nas formas dominantes de pensar foram muito mais extensas, impactando múltiplas esferas da vida social. No que diz respeito à expansão das ideias liberais no mundo "em desenvolvimento", consultar Biersteker (1995).

${ }^{9}$ A exposição mais completa desse ideário, desde seu surgimento, evolução dentro do BNDES e impacto imediato, encontra-se em Mourão (1994).
O reformismo liberal e o desenvolvimentismo-distributivo se expressaram também no plano político-partidário. As forças políticas de esquerda (PT, PCdoB, PCB etc.) e uma parte da centro-esquerda nacionalista (presente no PMDB e no PDT) propugnavam não pela derrubada do nacionaldesenvolvimentismo, mas por sua renovação. Enfim, por uma inflexão à esquerda. Do que se tratava? Pelo que se depreende da campanha eleitoral de Luiz Inácio Lula da Silva, em 1989, essa inflexão significava, de um lado, a "desprivatização do Estado", com o rompimento das articulações "espúrias" entre empresas estatais e empresas privadas e, de outro, a reorientação das políticas de Estado para a distribuição da renda. A presença da demanda distributiva nesse ideário dava conteúdo material às reivindicações presentes no movimento por democratização: ela traduzia as exigências de alteração das relações de poder entre segmentos sociais e, especialmente, as exigências de inclusão política das classes populares. Denominamos esse ideário de esquerda de "desenvolvimentismo estatista e distributivo".

A esse ideário contrapunha-se a alternativa liberalizante, no interior da qual é possível identificar dois ideários. Como se sabe, o ideário neoliberal ganhou relevância no fim dos anos 1970 em função das dificuldades de superar a recessão e a inflação daquela década com os tradicionais instrumentos keynesianos de gestão macroeconômica, predominantes especialmente na Europa, os quais reservavam elevado papel regulatório e intervencionista ao Estado. Os governos da primeira-ministra Margareth Thatcher, no Reino Unido, e do presidente Ronald Reagan, nos EUA, adotaram uma gestão econômica de orientação monetarista, priorizando o equilíbrio das finanças públicas e o combate à inflação em detrimento da preservação do emprego e dos rendimentos do trabalho, combatendo, portanto, as diretrizes keynesianas ${ }^{7}$. Aos poucos, a política monetarista foi associada a outras propostas, como a desregulamentação dos mercados, redução dos gastos sociais e supressão do intervencionismo do Estado, livre fluxo de capitais e de mercadorias. Isso impulsionou politicamente o neoliberalismo - uma doutrina existente desde o final da II Guerra Mundial, mas até então com limitada expressão política.

Esse neoliberalismo renovado se disseminou pelo mundo "ocidental" sob o impulso dos governos inglês e norte-americano e das agências econômicas multilaterais como o Fundo Monetário Internacional e o Banco Mundial. Adotou uma perspectiva puramente mercantil, tendo em vista a produtividade e a rentabilidade do capital e, como horizonte, uma economia globalizada ${ }^{8}$.

A outra variante liberalizante, o projeto de "integração competitiva", nasceu como reação à crise do Estado nacional-desenvolvimentista, o qual, estrangulado pela dívida externa e por desequilíbrios fiscais, perdeu condições, na década de 1980, de impulsionar o desenvolvimento brasileiro9. Tratava-se basicamente de reformar o velho desenvolvimentismo adaptando-o às concepções liberais que se tornavam dominantes. A ideia central do projeto de "integração competitiva" consistia em transferir do Estado para a iniciativa privada o motor do desenvolvimento brasileiro, reduzindo as funções empresariais do Estado e "abrindo" a economia brasileira para o exterior. Não se propugnava, porém, um "ajuste" passivo aos dinamismos do capitalismo mundial; propunha-se, diferentemente, que se promovesse uma reestruturação do sistema produtivo brasileiro para tornar a indústria brasileira competitiva no plano internacional. Daí a ênfase dos mentores e difusores do projeto de "integração competitiva" na formulação e execução de políticas industriais que estimulassem o empresariado privado a agir nessa direção. Neste aspecto, ele se distinguia do ideário neoliberal, pois o Estado manteria alguma capacidade regulatória e preservaria parte de sua missão como indutor do desenvolvimento. 
O ideário da "integração competitiva" também se distinguia do neoliberalismo por ser uma forma de afirmação nacional no plano internacional. Como consequência, essa vertente liberal almejava um Estado relativamente forte, com capacidade de comando sobre as atividades econômicas que se desenvolvem no seu território. Essa perspectiva esteve em sintonia intelectual com a reavaliação crítica do desenvolvimento industrial latino-americano que começara a ser feita no âmbito da Comissão Econômica para a América Latina (CEPAL) desde o início dos anos 1980 (Fajnzylber 1983). Segundo tal reavaliação, o padrão latino-americano de industrialização tornara-se insustentável, de um lado, por seu perfil imitativo, incapaz de gerar inovações tecnológicas e, de outro, em função de seu caráter autárquico, à margem da extraordinária onda de inovações técnicas e de gestão que marcaram a Terceira Revolução Industrial.

Na segunda metade dos anos 1980, a grande imprensa e as elites empresariais adotaram uma perspectiva cada vez mais liberal, embora imprecisa, cujo núcleo era o combate ao estatismo. Denunciava-se o intervencionismo estatal nas relações mercantis, especialmente o controle de preços, e o desequilíbrio das finanças públicas, identificado como fonte primeira da inflação. No limite, especialmente entre os economistas neoclássicos ortodoxos, esse liberalismo ganhava uma articulação ideológica mais definida e consistente, na forma de neoliberalismo. Nesse período ganhou força entre dirigentes e técnicos de alto nível na administração direta e nas empresas estatais, especialmente do Banco Nacional de Desenvolvimento Econômico e Social (BNDES), o mencionado ideário de "integração competitiva". No fim dessa década, ele se difundiu entre as elites empresariais privadas, mas de forma limitada, servindo de plataforma político-intelectual para a organização, por uma fração da grande indústria paulista, do Instituto de Estudos do Desenvolvimento Industrial (IEDI).

A ênfase dada a esses dois ideários liberalizantes na gênese do período recente faz contraponto com a literatura que analisa o processo de liberalização. A vertente que o vê de forma favorável tende a apagar o neoliberalismo como fonte de inspiração, como se a liberalização fosse um "ajuste" adaptativo ao movimento das coisas, do "mercado", como "elas devem ser" (Pinheiro \& Giambiagi 2006). Já a literatura crítica (Filgueras 2006; Barbosa \& Souza 2010) tende a reduzir o reformismo liberal ao neoliberalismo enfatizando a subordinação do Estado ao capitalismo internacional. Políticas não enquadráveis nesses moldes são vistas ora como equívocos ora como exceções que confirmam a regra. Tais modelos analíticos facilitam a polarização, mas simplificam, empobrecem e tornam equivocada a sua reconstrução histórico-sociológica.

O reformismo liberal também teve de se ajustar às demandas do movimento de democratização, tanto aquelas materializadas nos novos padrões de relacionamento entre os poderes de Estado fixados pela Carta de 1988, quanto às demandas por mais igualdade jurídica e material entre os cidadãos, encarnadas ou não na mesma Constituição. Essas pressões democratizantes se manterão no período seguinte e marcarão fortemente o tipo de liberalização que ocorreu no Brasil.

\section{Inflexão liberal e reorientação internacional do Brasil}

Durante o período da Guerra Fria, a orientação básica do Brasil em relação à ordem internacional consistiu em manter a "autonomia através da distância", resistindo à consolidação de instituições e regimes internacionais que pudessem congelar a hierarquia de poder mundial. Essa orientação política reforçava o protecionismo do Estado em relação à economia nacional e, precisamente por isso, se combinava ao modelo desenvolvimentista. 
${ }^{10}$ Contraditoriamente às tendências internacionais daquele contexto, a Carta de 1988 manteve o papel central do Estado na ordenação econômica, arranjo que suscitou diversas críticas de segmentos liberais (políticos e intelectuais) quanto ao suposto estatismo da Constituição. A respeito das disputas em torno da ordem econômica no processo constituinte, ver Pilatti (2008).
$11 \mathrm{Na}$ tradição realista das Relações Internacionais, o ordenamento mundial se encaminhou para um arranjo uni-multipolar, com a manutenção da primazia dos EUA. A esse respeito, ver Fiori, Medeiros e Serrano (2008).

12 Trata-se de outra forma de nomear o já mencionado ideário de "integração competitiva". Sobre a incorporação dessa perspectiva à política externa brasileira, ver especialmente Azambuja (1990).

13 Recorde-se que foi Itamar Franco quem lançou em 1993, na cidade de Santiago (Chile), o projeto de construir uma Área de Livre Comércio da América do Sul no prazo de dez anos, ampliando os horizontes do Mercosul.

14 Sobre as diferenças de política exterior entre os períodos de Cardoso e de Lula, consultar Vigevani e Cepaluni (2007). Estes autores contrapõem o que denominam "autonomia através da participação”, de Cardoso, à
No plano nacional, como vimos, a crise de hegemonia levou à perda da capacidade do Estado de conduzir a sociedade e a economia, o que produziu perda de dinamismo econômico, oscilações bruscas das taxas de crescimento e padrão inflacionário crônico e crescente. Essa perda de capacidade estatal ajudou a impulsionar uma variedade muito grande de atores coletivos em direção à democratização política, movimento que ganhou normatividade jurídica na Constituição de $1988^{10}$. Num ritmo mais lento e defasado, as relações Estado-economia foram se orientando em direção ao liberalismo econômico. Tais mudanças políticas internas foram balizadas por grandes transformações econômicas e políticas ocorridas em âmbito mundial: transnacionalização do capitalismo, disseminação internacional do neoliberalismo e fim da ordem bipolar da Guerra-Fria.

A despeito dessas grandes mudanças, o Brasil manteve sua política de autonomia na ordem internacional pela distância durante quase toda a década de 1980. Só a partir de 1989 - de modo cada vez mais nítido -, a orientação das elites brasileiras tornou-se favorável à integração do país à nova ordem internacional em formação, embora tentasse proteger os valores e interesses do Brasil nas instituições e organismos reguladores que se construíam (Vigevani, Oliveira \& Cintra 2003). Isso significava ir além da preservação da autonomia nacional. Com o fim das disputas Leste-Oeste e a derrocada do bloco soviético, as polaridades tornaram-se indefinidas e tornou-se predominante a interpretação de que a nova ordem internacional em formação abria possibilidades para uma maior projeção brasileira, pois a importância relativa de cada país passava a ser medida menos por seu peso militar e estratégico e mais por sua projeção econômico-comercial, científica e cultural (Amorim 1994; Abdenur 1994; Lafer \& Fonseca Jr. 1994). O protecionismo defensivo perdeu significado e depois da Guerra Fria era necessário participar, tornar-se um global player na construção e na gestão da ordem internacional, que não se esperava que fosse unipolar $^{11}$.

Nota-se, pois, que a perspectiva de "inserção competitiva" 12 - um dos projetos de reformismo liberal que balizou as lutas pela construção de uma nova forma de Estado que superasse a crise de hegemonia iniciada no início dos anos 1980 - tornou-se dominante entre os formuladores da política externa brasileira e moldou sua redefinição. O Mercosul, por exemplo, passou a ser entendido não só como um reforço da nova democracia (assim era interpretado nos anos 1980), mas também como a afirmação da posição econômica e política brasileira na luta por uma inserção favorável na nova ordem mundial. Essa nova orientação consolidou-se no governo de Itamar Franco (1993-1994), manteve-se no período de Cardoso e foi intensificada nos governos de Luiz Inácio Lula da Silva, cuja posição tornou inviável a implantação da Área de Livre Comércio das Américas proposta pelos EUA ${ }^{13}$. As variações de execução da estratégia de inserção externa derivaram de mudanças na cena internacional e das relações políticas internas: de um lado, a política unilateral do governo de George W. Bush, especialmente depois do atentado de 11 de setembro de 2001 e, de outro, o tom mais nacionalista e até "terceiro-mundista" que trouxe a chegada do Partido dos Trabalhadores ao centro do poder ${ }^{14}$.

O relevante aqui é enfatizar que a ambição de tornar-se potência (no sentido político limitado, não necessariamente militar), que estava implícita na nova orientação da política externa, teve implicações internas relevantes. Assim, a aposta em uma "inserção internacional competitiva" só seria factível se o Brasil tivesse um Estado sólido, com capacidade de comando sobre a economia e a sociedade e, também, uma economia com peso significativo do ponto de vista internacional. Nossa hipótese é que tais exigências internas ajudaram a filtrar a incorporação nacional do neoliberalismo, então dominante no Ocidente. De fato, caso o ideário neoliberal fosse plenamente adotado, teria se tornado 
"autonomia pela diversificação", de Lula. impossível a construção de um Estado com capacidade de indução sobre a economia e, ademais, haveria muita incerteza em relação à formação de uma base econômica ampla que sustentasse as ambições da elite do Brasil de tornar-se potência. Assim, é presumível que, pelo menos em parte, as ambições internacionais das elites brasileiras tenham contribuído para que as ideias neoliberais tenham sido mitigadas e só adotadas seletivamente.

Por outro lado, a perspectiva de inserção internacional competitiva pode ter contribuído para atenuar a perspectiva autárquica do remanescente nacionaldesenvolvimentismo. Na verdade, as ambições de converter o Brasil em potência no plano internacional reforçaram a conversão do velho e defensivo desenvolvimentismo ao projeto de integração competitiva no plano da estrutura produtiva. Assim, a defesa do protecionismo industrial frente à competição estrangeira foi em parte abandonada, mas preservada a base produtiva do país. Passou-se a defender o estímulo a diversas atividades - agricultura, indústria e serviços - para torná-las competitivas no plano internacional.

A reorientação da política externa, a absorção seletiva do ideário neoliberal e as transformações do ideário desenvolvimentista surgiram pouco a pouco e mediante agudas disputas político-ideológicas, possíveis apenas porque o processo brasileiro de transição foi inicialmente de democratização política e só depois de liberalização econômica. Em outras palavras, o processo de liberalização não foi produto de decisões tomadas de modo autocrático, mas de disputas e negociações no contexto da forma democrática de fazer política e de construção de um novo projeto hegemônico. Além disso, o processo de democratização não foi produto de um jogo disputado apenas por distintas facções da elite política: incluiu e dependeu também de diferentes modalidades de pressão popular sobre o sistema político, pressões que resultaram, dentre outros efeitos, na inclusão na Constituição de 1988 de um largo elenco de direitos políticos e sociais (inéditos no Brasil), cujas garantias condicionaram fortemente as políticas de Estado que se seguiram.

\section{Hegemonia liberal vs. ortodoxia neoliberal: o período Cardoso}

\footnotetext{
15 A expressão

"liberal-desenvolvimentista" que nos parece mais apropriada do que a de "integração competitiva” para fazer o contraponto ao ideário neoliberal - encontra-se em Sallum Jr. (1999).
}

Há amplo consenso entre os analistas à esquerda do espectro ideológico de que a corrente liberal mais ortodoxa, a neoliberal, foi hegemônica desde 1995 até hoje, sobretudo nos governos de Cardoso, materializando-se na política macroeconômica e em outras políticas públicas. Há aí, como já sublinhamos, uma simplificação que conduz à imprecisão. A partir de outro ângulo, reafirmamos o argumento anterior: apesar de o neoliberalismo ter balizado de forma marcante as políticas do Estado brasileiro desde a década de 1990, especialmente sua política macroeconômica, ele só definiu parcialmente as políticas de Estado.

Ancoradas principalmente nos interesses do "mercado financeiro" nacional e internacional que dominam o capitalismo financeiro atual (Chesnais 1994; Braga 1997), as ideias neoliberais tiveram de enfrentar resistências derivadas das ambições internacionais do Brasil, das ideias e interesses liberal-desenvolvimentistas ${ }^{15}$ vinculados ao capital produtivo nacional e das demandas igualitárias decorrentes do impulso para a democracia, as quais se traduziram em agudas disputas políticas e institucionais. Apesar desse impulso democratizante ter raízes inicialmente na classe média urbana, ele avançou incorporando demandas de auto-organização dos trabalhadores da indústria e dos serviços, seguindo adiante com o reforço das "demandas potenciais" da maioria pobre do eleitorado - passíveis de serem calculadas por quem detinha o poder - e com as pressões distributivas dos movimentos sociais e das associações de trabalhadores. 
${ }_{16}$ Nesse sentido, procede a comparação com os inspiradores neoliberais: os governos de Thatcher e de Reagan não efetivaram necessariamente muitos de seus postulados e objetivos, caso notável do desempenho do governo britânico quanto à performance econômica e ao equilíbrio fiscal (Colistete, Maluf \& Nakane, 1997).
A retórica neoliberal, já marcante no governo Collor, ganhou proeminência na medida em que a estabilidade monetária obtida com o Plano Real passou a ocupar o centro da agenda política no governo de Cardoso. A estabilidade substituiu a ênfase característica do Estado "varguista" no crescimento econômico e no emprego como alvos da política econômica. Essa centralidade foi acompanhada pelo predomínio da perspectiva de que só se poderia atingir o objetivo mediante políticas "ortodoxas", "universalmente" aceitas nos meios acadêmicos liberais e neoclássicos (Novelli 2007a; 2007b) sem depender da intervenção ad hoc do Estado no mercado, ao estilo heterodoxo da década de 1980.

O Banco Central (BC) converteu-se no núcleo da gestão macroeconômica: tornou-se o principal responsável pela definição das metas de inflação associando-as a uma política monetária rígida, a altíssimos níveis de juros e, a partir de 1999, a um regime de câmbio flutuante. O BC atuou com enorme independência em relação ao resto do governo e aos ministérios econômicos. Embora não tenha a independência legal em relação à "política", como desejam os ortodoxos, age como se a tivesse, com autonomia de ação. Isso garante, porém, que a Presidência da República possa intervir em casos extremos, como ocorreu na transição do primeiro para o segundo governo Cardoso, e não evita que se perceba, de forma geral, muita sintonia entre as políticas adotadas e as inclinações do mercado financeiro.

A política fiscal comandada pelo Ministério da Fazenda seguiu um modelo menos rígido que o recomendado pela ortodoxia, embora desde 1999 - depois de um acordo com o Fundo Monetário Internacional (FMI) e com os EUA tenha produzido um superávit primário sempre superior a 3,3\% do PIB (excluindo os pagamentos de juros devidos). A qualificação da política fiscal como menos rígida se justifica porque o superávit primário derivou do aumento extraordinário da carga tributária - que saltou de uma média de $25 \%$ do PIB, em 1980, para aproximadamente $35 \%$ do PIB a partir de 1995 - e não da redução dos gastos públicos, que aumentaram constantemente em relação ao PIB, com exceção dos anos mais agudos de crise (1999 e 2003). Além disso, se é verdade que há muito controle nos gastos dos municípios e estados federados, os limites para as despesas do governo central são mais flexíveis, exceto pela obrigação de produzir o superávit operacional. Essa flexibilidade fiscal permitiu que o Estado pudesse arcar com os altíssimos juros da dívida pública, atendesse algumas demandas distributivas e implantasse políticas sociais, satisfazendo as obrigações da Constituição de 1988. Em suma, também no Brasil os gastos públicos não foram reduzidos como recomenda a receita neoliberal ${ }^{16}$.

Houve notável perda de capacidade de intervenção do Estado no campo econômico, expressada no ritmo do programa de desestatização, nas privatizações de algumas grandes empresas estratégicas (caso emblemático da Companhia Vale do Rio Doce) e na adoção do modelo de Agências Reguladoras para diversos setores, como o de telecomunicações e o elétrico.

Embora a orientação neoliberal tenha conduzido a uma grande redução do papel empresarial do Estado, este não perdeu sua capacidade de regulação e, em algumas áreas, até a incrementou, mantendo capacidade considerável de intervir ativamente na vida econômica. Com efeito, o neoliberalismo se efetivou no núcleo das políticas macroeconômicas, mas não conseguiu se converter em diretriz orientadora da totalidade das políticas de Estado na esfera econômica.

Mesmo tendo havido um grande número de privatizações, parte de um setor tão importante como o elétrico foi mantido como propriedade de empresas estatais. O Estado ainda manteve grande poder de decisão sobre outros segmentos: no setor petroleiro, por exemplo, o Estado tornou-se o poder concedente de zonas de exploração e transformou em concessionária a Petrobras, 
mantendo-se como seu acionista majoritário e ainda lhe reservando o direito de manter as áreas onde já tinha operações.

A estratégia adotada pelo governo de Cardoso para privatizar e vender as concessões no setor de telecomunicações confirma o argumento anterior. Além de serem precedidos por uma lei que definiu as regras de funcionamento e a estrutura do setor pela criação de uma agência reguladora, vários leilões definiram as diferentes privatizações e concessões. O governo buscou atrair empresas transnacionais importantes para que participassem desses leilões. As empresas foram convidadas a apresentar propostas, com o governo oferecendo-lhes a possibilidade de receberem empréstimos do BNDES e de se associarem aos fundos de pensão de empresas estatais. Neste caso, a questão não era construir um Estado sólido, com capacidade de comando, mas de "tornar mais denso" o sistema econômico nacional e aumentar seu peso internacional com a incorporação de grandes prestadores mundiais de serviços de telecomunicações. Em termos práticos, o BNDES abrandou sua missão de banco de fomento do desenvolvimento nacional e se inclinou a uma política de financiamento das privatizações.

Além disso, o Estado manteve sob seu controle empresas privatizadas consideradas "de valor estratégico", assegurando-se uma golden share que the possibilita vetar negócios que considere nocivos aos interesses do país. Tal foi o caso da Embraer, fabricante nacional de aviões pequenos e médios.

Essa definição de "valor estratégico" foi crucial para impor limites às privatizações dos bancos estatais. De um lado, o governo federal estimulou a venda de todos os bancos que fossem propriedade dos governos estaduais - seja por estarem em má situação financeira, seja porque os considerava instrumentos de má gestão do dinheiro público e do desajuste fiscal -mas, de outro, manteve os bancos federais. O Banco do Brasil tem especial importância para o financiamento agrícola, enquanto a Caixa Econômica Federal é fundamental para o financiamento imobiliário, ambos entre os cinco maiores do país. Além disso, o governo federal preservou o seu banco para o desenvolvimento (BNDES), ícone do período nacional-desenvolvimentista e fonte principal de empréstimos de longo prazo para as empresas privadas. Todo o sistema de regulação bancária foi aperfeiçoado e submetido às regras internacionais da Basiléia. Dessa maneira, o Estado - além de seu poder normativo - manteve uma boa capacidade de atuar efetivamente, através do sistema financeiro estatal, sobre o nível de atividade e investimento dos diversos setores da economia.

Finalmente, na contramão da retórica neoliberal, em situações críticas, quando as políticas de estabilização e outras do repertório liberal ameaçaram destruir uma parte considerada relevante da indústria, os quadros "liberaldesenvolvimentistas" do governo e empresários envolvidos no problema (às vezes transnacionais) conseguiram que o Estado lhes desse alguma proteção e estímulo. Insistimos no argumento: essa inflexão só foi possível porque tais segmentos empresariais eram considerados chaves para o projeto de inserção competitiva e porque os diferentes grupos sociais atingidos (tecnocracia estatal, empresários e trabalhadores) reagiram às pressões e ao acirramento da competição internacional, conseguindo arrancar garantias ad hoc em um ambiente em que a política macroeconômica se encaminhava mais e mais à abertura desses setores.

Nessas condições, abriu-se um cenário de escolhas entre fundamentalismo neoliberal e liberal-desenvolvimentismo, de sorte que "o primeiro oferecia mais garantias imediatas de 'segurar o Real' - preservando o prestígio político difuso que ajudava o governo a manter suas posições nas várias arenas políticas - e mais riscos de médio e longo prazo, por conta do eventual crescimento da taxa de desemprego e de perturbações provenientes do sistema financeiro inter- 
nacional" (Sallum Jr. 1999, p.44). De outra parte, "o segundo prometia mais garantias de médio e longo prazo - maior impulso ao crescimento e equilíbrio das relações econômicas com o exterior e menor fragilidade em relação a oscilações bruscas do sistema financeiro internacional - porém menos segurança política de curto prazo, em função de eventual perturbação monetária derivada, por exemplo, de uma mudança na política cambial ou de juros" (Sallum Jr. 1999, p.44).

Essa equação de custos e benefícios indica que tais opções não podem ser interpretadas fora de seu contexto, qual seja, de centralidade política e econômica da agenda da estabilização e de pressões internas e externas. Não se trata de resumir tal explicação a um estilo de decisões ad hoc, mas de considerar o caráter contraditório de escolhas que não só opunham diferentes orientações no interior do campo liberal, mas tinham alcance relativamente limitado. Nada contradiz a adesão predominante à orientação neoliberal do primeiro governo Cardoso, porém, as pressões externas ao governo, as exigências políticoinstitucionais e as demandas de diferentes grupos sociais forjaram uma mitigação das políticas associadas ao neoliberalismo. Vale insistir e enfatizar que "para a corrente neoliberal dominante a prioridade era a estabilização" (Sallum Jr. 1999, p.33).

Assim, o ideário neoliberal foi incorporado às políticas de Estado de forma atenuada e seletiva. Mesmo no plano das ideias, não contou com um conjunto articulado e consistente de defensores, embora a imprensa veiculasse opiniões e análises de economistas, de consultorias econômicas e de segmentos empresariais inspiradas naquele ideário. De forma similar, os portadores do "liberaldesenvolvimentismo" atuaram no período Cardoso, especialmente no primeiro governo, mais como "guerrilheiros" defensores da indústria do que como "estrategistas do desenvolvimento", e parte de suas "vitórias" - a preservação do BNDES, da Petrobras e do Banco do Brasil, por exemplo - ocorreu menos como resultado da defesa articulada e sistemática de um ideário consistente do que pela falta de ação concertada dos partidários do ideário neoliberal. Após as formulações iniciais do ideário de "integração competitiva" não houve elaboração intelectual relevante que conformasse uma estratégia de desenvolvimento que tivesse nitidez e, assim, que pudesse agregar adeptos e orientar políticas consistentes. Manteve-se, dessa forma, como corrente liberal secundária durante todo o período.

Ainda que as iniciativas econômicas do período Cardoso não fossem resultado de um ideário bem definido, elas foram sustentadas por um conjunto de concepções e crenças que deram unidade de orientação e propósito ao bloco político hegemônico que sustentou a reestruturação do Estado. Tratava-se de um liberalismo econômico em construção, com limites mal definidos, que foram ganhando nitidez na medida em que as políticas de reforma foram se construindo de forma disputada; um liberalismo, ademais, polarizado entre atores inclinados seja ao neoliberalismo, seja ao liberal-desenvolvimentismo.

${ }^{17}$ Em Sallum Jr. (1999, pp.32-35) encontra-se referência ao conjunto de ideias que orientava a ação do bloco político hegemônico que aqui denominamos reformismo liberal enfatizando, porém, seu caráter ideológico pouco nítido e politicamente em construção.
Foi este reformismo liberal que se tornou hegemônico no plano nacional ${ }^{17}$. Ele foi o código comum que permitiu articular maioria parlamentar, burocratas e dirigentes do Estado, empresariado de todos os segmentos, meios de comunicação com penetração na classe média e mesmo entre os trabalhadores organizados.

Uma hegemonia sempre resulta na universalização de interesses através das ideias e, assim, da criação e utilização de pontes simbólicas e práticas entre os participantes do "sistema de dominação": (i) entre o setor capitalista preponderante (o financeiro) e os demais setores empresariais e (ii) entre os dirigentes do Estado, os quadros da administração e o conjunto da população, sob a 
${ }^{18}$ Essa concepção encontra-se em um documento governamental apresentado a um seminário internacional sobre a "terceira via" a conexão estabelecida no governo Cardoso entre políticas sociais, capacitação e inclusão social. Consultar Faria e Graeff (2000, p.1).
${ }^{19}$ Sobre as políticas sociais no governo Cardoso, ver Draibe (2003).

${ }^{20}$ Entendida como os grupos sociais que ganham a vida através do exercício qualificado de profissões especializadas de nível superior, como economistas, administradores, engenheiros, sociólogos etc., os quais trabalham usualmente como docentes universitários, consultores ou executivos.

${ }^{21}$ Tal incorporação deu-se graças à designação de cerca de 40 mil funcionários para as tarefas de direção e suposição de que essa nova forma de Estado estabeleceria relações mais democráticas com a sociedade.

No período de Cardoso, as mencionadas pontes simbólicas de inserção eram constituídas pelas noções de "estabilidade", "competitividade", "competência", “capacitação" e "inclusão social” (pois se reconhecia que o capitalismo operava numa sociedade "injusta") mediante a expansão dos "direitos sociais", da "solidariedade" ou da "proteção social". Estabilidade, competitividade e competência foram os valores que orientaram e justificaram a política econômica nesse ciclo, enquanto a capacitação era o eixo das políticas destinadas aos trabalhadores e pequenos produtores (ajuste às mudanças tecnológicas, empreendedorismo e a possibilidade de converter-se em bons empresários). A capacitação era também o fio ideológico que vinculava as políticas sociais à inclusão de segmentos mais empobrecidos ${ }^{18}$.

Finalmente, os direitos sociais, a solidariedade e a proteção social eram os lemas justificadores das políticas que buscavam priorizar os cidadãos excluídos ou precariamente incluídos na sociedade capitalista. Os direitos sociais, pilares de uma cidadania ampliada, estavam definidos na Constituição de 1988 e na Lei Orgânica de Assistência Social (LOAS). Ambas tentavam garantir as condições plenas para o exercício da democracia e fomentar a solidariedade dos setores privilegiados àqueles privados de seus direitos básicos ou em uma situação de miséria tal que requeriam proteção imediata. Não obstante, embora se tratasse de prestar solidariedade aos "de baixo", de proteger e assegurar os direitos de todos, isso também estava impregnado pela ideia de capacitação, no sentido de abrir a todos a possibilidade de participar plenamente da sociedade capitalista. Haveria que "garantir o peixe, mas também ensinar a pescar", pois a inserção na sociedade de mercado exigiria "talento", méritos individuais e ambição para a acumulação. Trata-se de uma concepção que, precisamente por atenuar a dimensão social das desigualdades, remete sua superação para o plano privado-individual.

As políticas sociais no governo de Cardoso foram em geral universais, sobretudo em relação à saúde e à educação básica. Quando existiu, a focalização ocorreu principalmente em termos regionais: por exemplo, o Programa da Comunidade Solidária visava a articular as diversas políticas universais nos municípios mais pobres do país. As políticas de transferência de renda, que atingiam as famílias abaixo da linha de pobreza com características específicas, como filhos pequenos em idade escolar, só ganharam importância no segundo mandato de Cardoso, substituindo as distribuições de cestas básicas e de outros produtos ${ }^{19}$. Essas políticas focalizadas estavam vinculadas à capacitação da geração futura, já que a transferência de renda era condicionada à comprovação da assiduidade escolar dos filhos ou à realização de controles de saúde.

Embora tais ideias preponderem no capitalismo contemporâneo, liderado pelo capital financeiro, a tradução das noções mencionadas em políticas concretas foi realizada basicamente por quadros de classe média profissional ${ }^{20}$, incorporados à equipe de funcionários públicos nos setores superiores da administração ${ }^{21}$. Há uma afinidade entre essa classe e tais ideias, já que estabilidade, competitividade, competência e mérito - e as ideias relacionadas de eficiência, racionalidade, capacitação e valor - são virtudes cultivadas por amplas parcelas da classe média profissional.

Ademais dos constrangimentos das políticas de inserção competitiva que balizaram a inserção brasileira no cenário internacional e das pressões sociais e políticas domésticas, cabe sublinhar algumas das pressões econômicas internacionais que contribuíram para moldar o programa liberal adotado no período. Embora bem-sucedido, o Plano Real de estabilização foi lançado quando o Brasil contava com um nível relativamente baixo de reservas cambiais. Ao 
assessoramento superior. Em 1998, representavam cerca de $3 \%$ dos quadros da administração pública.

22 Sobre a gestão econômica do segundo governo Cardoso, consultar Filgueras (2006, cap.6 e posfácio) e Oliveira e Turola (2003).

${ }^{23}$ Por diversas razões, deixaram o governo vários quadros identificados com o liberal-desenvolvimentismo, tais como José Roberto Mendonça de Barros, Luiz Carlos Mendonça de Barros e Luiz Carlos Bresser-Pereira, que ocuparam posições de destaque no primeiro mandato de Cardoso. José Serra, que foi Ministro do Planejamento, passou a ocupar o Ministério da Saúde. longo do primeiro mandato de Cardoso, a situação cambial brasileira continuou difícil em razão da crise mexicana de 1995, da crise asiática de 1997, da moratória russa, ocorrida no segundo semestre de 1998, o que levou o governo a elevar drasticamente as taxas de juros e a recorrer ao FMI e a instituições financeiras multilaterais. No inicio de 1999, já no segundo mandato de Cardoso, tornou-se insustentável preservar a política de sobrevalorização do Real que, a despeito de castigar fortemente diversos segmentos produtivos da indústria nacional, era até então a principal âncora da estabilidade monetária. Demitiu-se o presidente do Banco Central, Gustavo Franco, adotando-se na sequência uma política de flutuação cambial do Real.

A estabilidade não foi sacrificada. Pelo contrário, a despeito das dificuldades externas, ela até ganhou alicerces mais sólidos, pois a política de "câmbio flutuante" granjeou status de elemento essencial para manutenção da estabilidade e o "ajuste fiscal" passou a ser protegido por legislação complementar, a "Lei de Responsabilidade Fiscal", promulgada em maio de $2000^{22}$.

Não obstante, a incapacidade de reverter a vulnerabilidade externa da economia brasileira representou um obstáculo intransponível ao crescimento sustentado, fazendo naufragar as promessas e expectativas desenvolvimentistas com que Cardoso conquistara o segundo mandato. Também contribuiu para isso a redução, no segundo mandato, do peso da corrente "liberal-desenvolvimentista" na equipe econômica de governo ${ }^{23}$.

A política macroeconômica custou a deterioração das finanças públicas, a progressiva vulnerabilidade externa, um "padrão anêmico de crescimento", elevadas taxas de juros e aumento do desemprego, ensejando ao final um "sentimento generalizado de mudança; o país clamava pela volta do crescimento, do emprego, enfim, do dinamismo econômico que fora sacrificado no altar da estabilidade monetária" (Paulino 2010, p.309). As dificuldades econômicas - mesmo para um governo reeleito com ampla maioria - refletiram-se na deterioração da capacidade política do governo, embora não a ponto de produzir uma crise de governabilidade.

Nesse contexto, um aprofundamento da liberalização, com radicalização das privatizações, aceleração da desregulamentação e intensificação da transnacionalização da economia nacional, tornou-se politicamente impraticável, tanto pela escassez de instrumentos econômicos quanto de estoque de incentivos políticos. Não é casual que, a partir desse momento, o cenário sociopolítico comece a se mover, agora com sinal cruzado, isto é, em direção a uma nova coalizão que pudesse empunhar de novo as bandeiras do desenvolvimento e da defesa dos interesses nacionais, movimento que iria desembocar na candidatura de Lula em 2002. Esta coalizão incluiu os segmentos mais organizados dos trabalhadores (suas bases mais tradicionais), setores progressistas de classe média e, de forma inédita, parcelas de grupos empresariais, especialmente de setores produtivos mais duramente castigados pelas políticas de desregulamentação e pela abertura à concorrência internacional ${ }^{24}$.

\section{O liberalismo econômico nos tempos de Lula}

${ }^{24}$ Simbolicamente, essa aliança se consumou na composição da chapa presidencial com a dobradinha entre Lula (PT) e do empresário José de Alencar (então do Partido Liberal).

25 A esse respeito, ver, entre outros: Sallum Jr. e Kugelmas (2005), Filgueiras e Gonçalves
Há várias análises sobre a conversão de Lula e da direção do Partido dos Trabalhadores às políticas macroeconômicas de seu antecessor, inflexão expressa na prioridade que se deu à estabilidade da moeda, à manutenção do sistema de metas da inflação, ao regime de câmbio flutuante e também ao ajuste fiscal para sustentar o superávit primário e o respeito aos contratos ${ }^{25}$.

O elemento-chave que permite ligar os dois períodos é a decisão de eleger a estabilidade monetária como ação estruturante da governabilidade a ser construída, posição anunciada já em 22 de junho de 2002, no decorrer da campanha 
(2007), Paulani (2008) e Novelli (2007a). Ainda sobre o governo Lula, sob outra perspectiva, ver também Singer (2012).

${ }^{26} \mathrm{O}$ abandono de posições originais mais radicais e a adoção de outras mais moderadas foi uma inflexão mais antiga na história do PT, mas este documento é emblemático porque, embora reafirme ideias consagradas como "reformas estruturais" $\mathrm{e}$ se refira ao "esgotamento do atual modelo", assume pela primeira vez pública e textualmente que a "premissa dessa transição será naturalmente o respeito aos contratos e obrigações do país" (Lula da Silva 2002).

${ }^{27}$ Filgueiras e Gonçalves (2007, p.113) apresentam como mostra o aumento constante, de 1997 a 2007, do Índice de Liberdade Econômica elaborado pela Heritage Foundation, estruturado com base no contexto macroeconômico, incluindo o marco regulatório para as empresas, especialmente estrangeiras, a segurança jurídica, os direitos de propriedade, a regulação dos mercados de trabalho e de capitais.

28 Trata-se do afastamento das bases tradicionais vinculadas aos trabalhadores organizados e aos setores médios e da aproximação com o "subproletariado". Tal inflexão congrega ingredientes de esquerda (igualdade social e distributivismo) e de direita (afastamento do programa originário, continuidade da política macroeconômica).

${ }^{29}$ Um balanço desse período, de uma perspectiva

"desenvolvimentista", encontra-se em Barbosa e Souza (2010). Nele, a polarização tradicional, que dissocia completamente desenvolvimentismo e liberalismo, torna difícil diferenciá-lo do nacional-desenvolvimentismo. Notável que os autores não façam qualquer análise das conexões entre o desenvolvimentismo que defendem e a competitividade global do país.

${ }^{30}$ Somente em 22 de dezembro de 2009 foi lançado o primeiro edital do governo eleitoral, por ocasião da divulgação da "Carta ao Povo Brasileiro" 26 . Além disso, muitas das reformas liberais do período anterior não foram modificadas, mantendo-se vigentes a eliminação dos privilégios das empresas nacionais, os regimes de concessões públicas na relação com o capital privado (que depois evoluiu para os sistemas de parceria e de partilha), as regras para a gestão fiscal equilibrada e a autonomia operacional do Banco Central $^{27}$.

No início, o governo Lula preocupou-se fundamentalmente em acalmar os mercados mantendo as políticas anteriores e até mesmo aumentando o superávit fiscal prometido por Cardoso ao FMI. Barbosa e Souza (2010) qualificam essa política macroeconômica como o "ajuste necessário", que se traduziu, dentre outras medidas, em elevação das metas de inflação, manutenção da política de flutuação do Real, aumento da taxa Selic de juros até o patamar de $25 \%$ a.a. e ampliação do superávit primário de $3,75 \%$ para 4,25\% do PIB. Além de estancar os efeitos inflacionários e a depreciação cambial decorrentes do ano eleitoral, o governo pretendeu sinalizar claramente seu domínio sobre a dívida pública, o controle rígido sobre os gastos públicos (da União, sobretudo) e o respeito aos contratos.

Mais ainda: Lula continuou com o programa de reformas nos sistemas de pensões e tributário iniciado no período anterior. Para a maioria dos militantes do PT e boa parte do governo (com a lógica exceção da equipe econômica), essa continuidade foi assumida de má vontade, mas de forma resignada, pois era considerada inevitável para garantir a estabilidade. Prenunciava-se, assim, a mudança observada por Singer (2012) nas bases sociais, políticas e eleitorais do petismo, realinhamento nomeado pelo autor como "lulismo"28.

O liberalismo econômico se manteve, mas perdeu muito vigor reformista, especialmente a vertente proveniente da corrente neoliberal ${ }^{29}$. Buscou-se, de várias maneiras, compatibilizar a herança do período Cardoso com o antigo conteúdo programático do Partido dos Trabalhadores - maior presença do Estado na vida social, proteção às empresas de capital nacional, principalmente às pequenas empresas, melhor distribuição da renda e proteção aos trabalhadores mais pobres.

Em primeiro lugar, a ação governamental enfatizou as vantagens da estabilidade econômica para os setores pobres e para a geração de um crescimento duradouro e sustentável. O argumento não era novo, mas adquiriu outra coloração ao ser utilizado por um governo e um presidente identificados com os setores populares.

Ademais, o governo de Lula interrompeu o processo de privatizações e, com isso, evitou a reação crítica das correntes de esquerda. Como contribuição própria à construção dessa nova forma de Estado, propôs a figura da "parceria" como mecanismo de articulação entre o setor público e as empresas privadas. Essa iniciativa foi aprovada pelo Congresso em fins de dezembro de 2004, com posterior promulgação da lei que regula as associações público-privadas para obras de infraestrutura. Nessas associações, o Estado define o que fazer, conservando o papel dirigente e realizando parte dos investimentos; quando a obra termina, é óbvio, as empresas privadas se convertem em exploradoras dos serviços (estradas, ferrovias, metrô) com uma rentabilidade mínima garantida por um fundo público. Essa iniciativa inovadora não teve, porém, resultados práticos relevantes no plano federal ${ }^{30}$.

Finalmente, a convergência entre a necessidade de garantir a estabilidade econômica e as posições originais do PT foi obtida graças à implantação de uma série de políticas orientadas a democratizar o acesso aos bens e serviços públicos e à abertura de novos canais de ascensão social. Para tanto, aumentou-se a renda real dos cidadãos já incluídos, mas situados nas camadas infe- 
federal com essa modalidade de contrato, para concessão de serviços de irrigação em Petrolina, Pernambuco. A licitação se encerrou com vencedor apenas em $23 \mathrm{de}$ setembro de 2010, último ano do segundo mandato de Lula.

${ }^{31}$ No âmbito do PAC ainda foram abrigadas outras iniciativas emblemáticas, como o Programa Luz Para Todos, que desde seu início atingiu quase 15 milhões de pessoas, e o Programa Minha Casa Minha Vida, que em suas duas versões iniciais estabeleceu a audaciosa meta de construção de mais de três milhões de unidades habitacionais.

${ }^{32}$ A esse respeito, ver Goy, Salvador e Nagakawa (2008) e Safatle (2008).

33 Para uma análise das "duas almas" do petismo, das contradições de seu ideário e como estas afloraram na experiência de governo, ver Singer (2012).

34 A expressão foi cunhada por Marco Aurélio Garcia, assessor da Presidência da República, em entrevista à Revista Teoria e Debate em $1^{\circ}$ de novembro de 2006.

35 Além da presença de Henrique Meirelles no BC, os Ministérios da Agricultura, Pecuária e Abastecimento e do riores da pirâmide social, e ampliou-se a cobertura a todos os brasileiros situados abaixo da linha de pobreza, considerados não apenas como indivíduos, mas também como famílias.

Quando Lula foi reeleito em 2006, todos esses programas foram mantidos e até ampliados. Como a estabilidade já parecia assegurada, o crescimento econômico e os investimentos públicos (sobretudo em infraestrutura) assumiram papel principal. O Plano de Aceleração do Crescimento (PAC), um programa de investimentos anunciado em janeiro de 2007, tornou-se onipresente e ganhou expressão e visibilidade, sobretudo, por sua incidência em grandes empreendimentos, como portos e usinas energéticas, e em obras de infraestrutura urbana. Ainda assim, trata-se de um programa relativamente limitado: além do fato de que muitos dos investimentos que o constituíram já estivessem previstos, os recursos totais equivaliam, no máximo, a $0,6 \%$ do Produto Interno Bruto (PIB) em 2007, ao passo que o pagamento de juros da dívida no mesmo período consumiu 4,7\% do PIB (Filgueiras \& Gonçalves 2007, p.201) ${ }^{31}$.

É preciso reconhecer que o governo ampliou a intervenção estatal através de outros mecanismos, mas sem obedecer a regras gerais. Além de aumentar a capacidade de empréstimos do BNDES, destinado a oferecer financiamentos produtivos em longo prazo e com juros baixos, o governo lançou uma série de iniciativas fragmentárias para recuperar as empresas estatais que não foram privatizadas (caso da Eletrobrás, por exemplo) e que permitiram que as mesmas se associassem a empresas privadas para aumentar os investimentos ${ }^{32}$. Irrigado com recursos do Tesouro, o BNDES redirecionou suas prioridades para investimentos estruturais sob a lógica do desenvolvimento de empresas nacionais, diferente do governo anterior, que privilegiou o financiamento das privatizações. Assim procurou melhorar a competitividade das empresas brasileiras em relação às multinacionais que operam no país (no setor das telecomunicações, por exemplo), além de incentivar as companhias nacionais a se expandirem para o exterior. Em suma, e embora devêssemos examinar com mais cuidado esse novo ativismo estatal, há claras evidências de uma ênfase liberaldesenvolvimentista, de orientação autenticamente capitalista, jamais contestada pelo governo petista ${ }^{33}$.

Ao preservar a estabilidade mediante políticas relativamente similares às de Cardoso, Lula ganhou um forte respaldo do mercado financeiro e do empresariado, especialmente quando a convergência entre a política macroeconômica herdada e o ideário político do PT, num contexto mundial excepcionalmente favorável (até dezembro de 2008), permitiu recuperar o crescimento num nível modesto (em torno de 4,5\% a.a. até a crise), mas superior ao período anterior e aparentemente sustentável. De fato, as políticas que visavam à garantia dessa convergência, sobretudo aquelas que buscavam a democratização do crédito e o aumento dos gastos com proteção social, produziram uma espécie de "crescimento através da distribuição" 34 , cuja conjunção permitiu a monetarização de áreas pobres e a melhora de regiões atrasadas, em muitos casos a "taxas chinesas", quer dizer, a um ritmo muito rápido (Mendonça de Barros \& Pereira 2006).

Estabilidade e crescimento ensejaram a fórmula que permitiu que Lula mantivesse o apoio dos empresários. No entanto, isso não impediu alguns desacordos pontuais nem certa desconfiança, seja pela presença de sindicalistas e líderes de movimentos sociais no governo, seja pela tolerância governamental a algumas ações desses movimentos. Mas o ponto central é que a combinação de estabilidade e crescimento garantiu o apoio dos empresários ao governo, aliança que já se traduzira desde 2003 em participação ministerial ${ }^{35}$.

No entanto, a dimensão mais importante da já mencionada convergência foi a ampliação do significado anterior do termo "proteção social". Essa expressão 
Desenvolvimento, Indústria e Comércio Exterior foram ocupados desde o início de governo por representantes do empresariado,

respectivamente, Roberto Rodrigues e Luiz Fernando Furlan. Pode-se encontrar uma análise sobre a heterogeneidade e a presença empresariais no governo de Lula em Sallum Jr. e Kugelmas (2004, pp.273-285). referia-se, no período de Cardoso, à decisão de transferir recursos para as famílias com renda inferior à linha de pobreza que tivessem filhos pequenos, crianças em idade escolar ou alguma outra característica que justificasse o auxílio. Essa proteção obrigava as famílias beneficiadas a manter seus filhos na escola, levá-los aos centros de saúde para vacinação e várias outras obrigações. Com isso, buscava-se que as políticas de solidariedade contribuíssem para que os excluídos superassem sua situação, alfabetizando-se ou associando-se em cooperativas de produção ou comercialização para enfrentar melhor os rigores do mercado.

Com Lula, a proteção foi ampliada e se estendeu a todas as famílias que estavam abaixo da linha de pobreza, em vez de incluir apenas aquelas com características especiais. Assim, as famílias beneficiadas pelos planos de transferência de renda passaram de 5,6 milhões para 11,2 milhões. Depois de algumas hesitações, voltou-se a cobrar contrapartidas dos beneficiados e o governo fez um esforço para transformar tais obrigações em contrato (Cohn \& Fonseca 2004). A cobertura aos mais pobres, os recursos destinados a programas sociais e o salário mínimo real aumentaram num ritmo maior que o PIB. Ao mesmo tempo, os fundos destinados às políticas universais de saúde e educação aumentaram no ritmo do crescimento geral da economia (Filgueiras \& Gonçalves 2007, p.162). Houve, portanto, uma inversão de prioridades em relação ao período de Cardoso, o que, é claro, teve efeitos políticos importantes, como se verá mais adiante.

O governo não se limitou a ampliar os programas destinados aos setores mais pobres. A decisão de universalizar a proteção social materializou-se também através da democratização do acesso a certos recursos para os estratos que estavam acima da linha de pobreza. Para isso, já desde o primeiro governo de Lula, foram introduzidas alterações nos mecanismos de crédito bancário que permitiram que os assalariados legalmente registrados e aposentados do setor privado, pertencentes ao Instituto Nacional da Previdência Social (INSS), tivessem acesso a empréstimos com custos inferiores aos usuais ("empréstimo consignado"), mediante desconto em seus salários ou aposentadorias.

A proteção se generalizou também através das políticas destinadas a ampliar o acesso à educação superior para os setores de renda média baixa, a saber, operários qualificados e baixa classe média, como trabalhadores assalariados urbanos do comércio e serviços, autônomos não profissionais etc. Destacam-se quatro programas: (i) o ProUni, que distribui bolsas para jovens com um bom desempenho na escola secundária, de famílias até certo limite de renda, para que estudem em escolas superiores privadas inscritas no programa; (ii) o FIES, que concede financiamento de longo prazo para estudantes de nível superior em escolas particulares, frequentadas em geral por aqueles com menos chances de competir; (iii) o ReUni, que amplia o escopo, atualiza os currículos e aumenta a quantidade de alunos formados nas universidades públicas federais; (iv) os programas de cotas nas escolas de nível superior, que privilegiam o acesso de estudantes vindos de escolas secundárias públicas e minorias como negros, mulatos e índios. Em todos esses casos, o objetivo consistia em apoiar a ascensão social dos jovens que, comparativamente, enfrentam mais dificuldades.

Há que sublinhar, ainda, a já mencionada política de progressiva valorização do salário mínimo, marcante no período Lula: elevação de $105 \%$ em termos reais e de $53 \%$ em relação ao custo médio da cesta básica. Essa democratização da renda atingiu positivamente trabalhadores da ativa e os dependentes do sistema previdenciário.

Em suma, "Bolsa Família, salário mínimo e expansão do crédito, somados aos programas específicos, e com o pano de fundo da diminuição dos preços da 
${ }^{36}$ Sobre esta questão ver Fernandes (1966; 1975; 1989).

${ }^{37}$ Essas afirmações baseiam-se nas agudas observações de Francisco de Oliveira sobre a nova classe no poder, em intuições pessoais não sistemáticas e em duas pesquisas, uma sobre a composição dos quadros de direção e assessoria (DAS) do governo de Lula e outra sobre a classe política, isto é, os deputados federais dos períodos iniciados em 1998 e 2002, cujos resultados foram publicados em Araújo (2007). Ainda sobre o mesmo tema, ver Rodrigues (2006). ${ }^{38}$ A esquerda do PT e, principalmente, a que se distanciou do partido a partir dos escândalos de corrupção de 2005, usa o termo clássico da linguagem gramsciana "transformismo" para caracterizar esse processo de "integração". O qualificativo é utilizado como contraponto às cesta básica, resultaram em diminuição da pobreza a partir de 2004" (Singer 2012, p.68) foram políticas que, em conjunto, protegeram não só os excluídos da competição - por idade, doença ou condições de vida miseráveis - mas também certos setores mais bem posicionados como os operários qualificados e a baixa classe média que participam da sociedade competitiva, mas em condições desfavoráveis.

Claro que existe uma diferença importante entre os objetivos de um conjunto de políticas públicas e os efeitos concretos sobre os alvos daquelas políticas. Isso se dá especialmente em relação às políticas educativas: a literatura sociológica demonstra que a universalização da educação pode criar cidadãos mais capazes, mas isso não necessariamente produz alterações significativas no sistema de estratificação socioeconômica ${ }^{36}$. Ainda que o sistema não se altere estruturalmente, tais iniciativas melhoram significativamente as possibilidades de ascensão das classes médias baixas.

Finalmente, há de sublinhar um efeito importante da abertura de maiores oportunidades de ascensão social, ainda que elas não se concretizem em sua totalidade: essa abertura tende a produzir maior adesão dos beneficiados à ordem competitiva, ou seja, ao sistema capitalista que a sustenta e ao Estado que a comanda. Este tem sido um dos caminhos de aprofundamento da hegemonia liberal no Brasil: permitiu, graças à democratização das oportunidades, o maior crescimento econômico e a ampliação do consumo, a incorporação sociocultural de setores subalternos e intermediários que, embora já participassem do sistema, faziam-no como em uma corrida de obstáculos muito difícil de superar.

A acomodação entre os resultados do reformismo liberal - herdados do período Cardoso - e o ideário do PT foi traduzida em políticas públicas por dirigentes diferentes dos que ocupavam os postos superiores da administração durante a gestão Cardoso. No governo Lula também havia presença significativa de funcionários pertencentes à classe média profissional, mas em menor proporção. A maior parte dos quadros incorporados ao governo tinha origem, do ponto de vista social e ocupacional, na baixa classe média. Mas é central salientar outra diferença qualitativa: de maneira geral, esse pessoal tinha filiação e militância partidária. Na maioria, haviam sido dirigentes ou líderes de associações sindicais e de movimentos sociais ${ }^{37}$.

Essa é outra das vias pelas quais a hegemonia liberal foi se aprofundando nos governos de Lula. O governo incorporou como parte do pessoal do Estado setores mais baixos da pirâmide social e, ainda mais importante, um número considerável de representantes de associações sindicais e de movimentos populares. A incorporação sociocultural de estratos sociais intermediários e a absorção de líderes populares na gestão do Estado, num esquema de convivência com as correntes liberais hegemônicas do empresariado e com os setores clientelistas e conservadores da "classe política", atenuaram o potencial transformador do PT e de seus aliados de esquerda. De fato, esse processo de ajuste tinha começado já nos anos 1990, mas acentuou-se depois da conquista do poder central $^{38}$. O fato é que o governo de Lula foi muito eficaz na consolidação do sistema de dominação social e da nova forma de Estado inaugurada em 1995: politicamente democrática e moderadamente liberal no plano econômico.

Em suma, no período de Lula a aceitação da sociedade de mercado como modo de vida expandiu-se socialmente, sobretudo através da difusão do consumo, conformando "o terceiro padrão de mudança social que se encontra em curso desde 2004 [que] demarca a combinação entre o crescimento da renda nacional per capita e a redução importante da desigualdade pessoal da renda" (Pochmann 2010, p.648), inclusão que incidiu mais fortemente sobre a base da pirâmide social. 


\section{Conclusões: limitações e dilemas da forma contemporânea de Estado}

possibilidades transformadoras, quiçá "revolucionárias", não realizadas pelo partido.

${ }^{39}$ A respeito das contradições entre reforma gradual e pacto conservador, ver Singer (2012) e Velasco e Cruz (2011).

${ }^{40}$ A despeito das diferenças ideológicas e/ou políticas entre essas forças rivais (PSDB e PT) e por força da similitude da política macroeconômica, aparentemente a

"modernização" institucional do Estado teria sido completada, restando "apenas" a disputa quanto à melhor coalizão sociopolítica para conduzir esse processo.
Buscamos evidenciar o caráter atenuado e seletivo com que o neoliberalismo foi incorporado às políticas de Estado no Brasil contemporâneo. Ele foi sempre limitado pelas demandas desenvolvimentistas, de fortalecer o sistema produtivo e de projetar o país no exterior, e pelas exigências de democratização substantiva que acompanharam a luta pela democratização política. Nesse sentido, talvez fosse melhor identificar como hegemônico, no Brasil contemporâneo, um ideário liberal moderado e pouco ortodoxo, sem consistência doutrinária: um ideário que valoriza a sociedade mercantil, o capitalismo, mas não exclui, e até admite, a intervenção do Estado, seja para reduzir as diferenças materiais e culturais muito grandes do país, seja para promover a expansão da riqueza e a capacidade de competitividade internacional do país.

Não obstante a sua especificidade, o período de Lula continua e aprofunda o movimento iniciado no período de Cardoso - combinando a manutenção da política macroeconômica, notadamente em suas dimensões cambial e monetária, à qual foi agregada um maior impulso desenvolvimentista e forte ação distributiva ${ }^{39}$. Pôde-se, assim, consolidar a hegemonia liberal e a democracia de 1988 como sistemas de dominação social.

Sob o impulso das políticas de Estado, foram provocadas não só alterações socioeconômicas que transformaram e expandiram a sociedade de mercado, como esta foi reforçada ideologicamente, tornando mais críveis, palpáveis e mensuráveis as promessas de acesso tanto dos "excluídos" como de segmentos "de baixo" da pirâmide social, posto que tais demandas seriam parcial ou integralmente efetivadas.

Nesses termos, não chega a ser de todo imprópria a percepção de que o petismo parece cumprir a missão outrora pleiteada pelo velho Partido Comunista Brasileiro, qual seja, a de consumar a etapa da revolução democráticoburguesa no Brasil ${ }^{40}$. Se outras etapas virão, só o tempo poderá responder, mas a julgar pelo modelo de Estado ora forjado é improvável que se consumem rupturas.

O processo de esmaecimento do ideário neoliberal e de aprofundamento da hegemonia liberal pode ser melhor percebido observando-se a maneira como, nos períodos de Cardoso e de Lula, em um ambiente institucional solidamente democrático, as noções centrais que orientaram a política macroeconômica e as políticas em favor do mercado se articularam com outras que justificavam ações governamentais em prol dos menos favorecidos, com gradações e alcances diferentes. Nesse sentido, "os alicerces foram lançados, tanto no sentido do aperfeiçoamento do regime democrático, com a crescente aceitação das regras do jogo, quanto à elaboração de uma nova agenda desenvolvimentista" (Diniz 2013, p.18).

Cabe enfatizar, mais uma vez, o que já se sublinhou ao longo do texto: o liberalismo econômico moderado que orientou as políticas do Estado brasileiro contemporâneo é resultado acomodatício de pressões e contrapressões entre forças sociopolíticas que procuraram superar o antigo Estado autoritário e nacional-desenvolvimentista. Ele foi moldado pela luta entre atores orientados pelos ideários neoliberal, liberal-desenvolvimentista e do desenvolvimentismo estatista e distributivista, os quais definiram seus contornos, ainda que pouco precisos, ajustando suas demandas e compondo-se mutuamente em todo o período considerado. Ao longo dos quatro governos analisados, as políticas de Estado tiveram afinidade maior ora com um, ora com outro daqueles ideários. Nos períodos em que a questão da estabilidade era aguda, as políticas associadas ao neoliberalismo tiveram proeminência, como no período Cardoso e no começo do período Lula. Mas, reiteramos, proeminência apenas, pois se ajus- 
${ }^{41}$ No máximo, o país cresceu $4 \%$ ao ano durante o período Lula, quando as condições externas, pelo menos até final de 2008, eram muito favoráveis, com taxa muito inferior ao crescimento de $7,1 \%$ ao ano entre $1947-1980$ (Contas Nacionais, FGV). Em 1980, o produto per capita do Brasil era 0,41 do equivalente da Europa Ocidental; em 2010, esta proporção caiu para 0,31 (University of Groningen 2013). taram às pressões políticas afins com o liberal-desenvolvimentismo e a democracia substantiva. Políticas orientadas para a inclusão social ganharam bastante ênfase no período Lula, mas dissociadas do estatismo desenvolvimentista a que estavam ligadas originalmente, acomodando-se aos padrões liberais predominantes. As demandas afins ao ideário liberal-desenvolvimentista - investimento público e privado, produtividade, câmbio favorável etc. foram as que mais dificuldades tiveram para se impor frente às àquelas vinculadas à estabilidade econômica ou à democracia substantiva.

Com efeito, as retóricas do desenvolvimento e mesmo do desenvolvimentismo estiveram presentes de modo crescente no período analisado. Da mesma forma, ocorreram políticas associáveis ao liberal-desenvolvimentismo. Mas isso não ocorreu de forma contínua: em alguma medida no primeiro governo Cardoso; mais no segundo governo Lula do que no primeiro. Mais importante ainda: tais políticas não parecem ter obedecido a uma estratégia definida em qualquer dos governos e, menos ainda, no período como um todo. Com efeito, o projeto de "integração competitiva", nascido na segunda metade dos anos 1980, não teve portadores políticos fortes o suficiente para dar-lhe consistência e, especialmente, torná-lo hegemônico como orientador das políticas do Estado. Esta talvez seja uma das razões pelas quais o país, embora tenha alcançado estabilidade econômica e reduzido a desigualdade socioeconômica, não conseguiu taxas de crescimento econômico comparáveis aos do período nacional-desenvolvimentista, tendo reduzido a participação econômica que tinha até os anos 1980 no PIB mundial ${ }^{41}$. Explicação à qual ainda poderiam ser agregados os obstáculos externos e os constrangimentos ao crescimento econômico internacional, a proeminência do capital financeiro e o desempenho subordinado do capital produtivo nacional.

Em síntese, as políticas afinadas com o liberal-desenvolvimentismo não tiveram capacidade de conduzir o país a uma integração competitiva relevante na economia mundial. Não há, contudo, como discutir aqui as bases sociais da frágil sustentação sociopolítica do projeto de "integração competitiva", especialmente a posição, o peso econômico e a influência política do empresariado industrial a esse respeito.

Outras limitações importantes da orientação econômica deste Estado dizem respeito a aspectos em que ela se entrecruza com o processo de democratização. De um lado, o sistema tributário, além de muito complexo, onera muito pouco a propriedade - especialmente heranças, grandes fortunas, doações e a propriedade urbana - o que determina uma acumulação de desigualdades socioeconômicas. De outra parte, a organização estatal sofre de inchaço e sobreposição de leis, normas e regulamentos e de exacerbado burocratismo. O que foi inicialmente reação saudável do movimento de democratização aos escândalos de corrupção e às práticas patrimonialistas na administração pública transformou o Estado em agente lento e pouco eficiente de desenvolvimento.

A despeito de todas essas limitações - e, sobretudo, de estar longe de superar as desigualdades estruturais sociais que marcam sua sociedade - a forma de Estado que se consumou no Brasil the conferiu estabilidade política e institucional no período analisado, notadamente porque se constituiu um pacto que permitiu, de um lado, preservar e mesmo ampliar os ganhos do capital e, de outro, tornar a democracia mais substantiva mediante um impulso distributivo. Ou seja, a concertação no âmbito das políticas do Estado em relação à economia foi determinante para a sustentação do sistema político. 
Brasilio Sallum Jr. (brasiliosallum@gmail.com) é Professor Titular do Departamento de Sociologia da Universidade de São Paulo (USP) e pesquisador do Centro de Estudos de Cultura Contemporânea (Cedec). Vínculo institucional: Departamento de Sociologia, USP, São Paulo, SP, Brasil.

Jefferson O. Goulart (jgoulart@faac.unesp.br) é Doutor em Ciência Política pela Universidade de São Paulo (USP), Professor do Departamento de Ciências Humanas da Universidade Estadual Paulista (Unesp) e pesquisador do Cedec. Vínculo institucional: Departamento de Ciências Humanas, UNESP, Bauru, SP, Brasil.

\section{Referências}

Abdenur, R., 1994. A política externa brasileira e o sentimento de exclusão. In G. Fonseca Jr. \& S. Castro, eds. Temas de Política Externa Brasileira II. São Paulo: Paz e Terra.

Amorim, C., 1994. Uma diplomacia voltada para o desenvolvimento e a democracia. In G. Fonseca Jr. \& S. Castro, eds. Temas de Política Externa Brasileira II. São Paulo: Paz e Terra.

Araújo, M.C., ed. 2007. Governo Lula: contornos sociais e políticos da elite do poder. Rio de Janeiro: CPDOC-FGV.

Azambuja, M., 1990. A política externa do governo Collor. Palestra proferida no Instituto de Estudos Avançados da Universidade de São Paulo (USP). Série Documentos IEA-USP, 19 out.

Barbosa, N. \& Souza, J.A.P., 2010. A inflexão do governo Lula: política econômica, crescimento e distribuição de renda. In E. Sader \& M.A. Garcia, eds. Brasil: entre o Passado e o Futuro. São Paulo: Boitempo Editorial.

Biersteker, T.J., 1995. The ‘Triumph’ of Liberal Economic Ideas in the Developing World. In B. Stallings, ed. Global Change, Regional Response: The New Economic Context of Development. Cambridge, UK: Cambridge University Press.

Braga, J.C., 1997. Financeirização Global. O padrão sistêmico de riqueza do capitalismo contemporâneo. In M.C. Tavares \& J.L. Fiori, eds. Poder e dinheiro. Petrópolis: Vozes.

Carvalho, J.M., 2002. Cidadania no Brasil: o longo caminho. Rio de Janeiro: Civilização Brasileira.

Chesnais, F., 1994. La mondialization du capital. Paris: Syros.

Colistete, R.; Maluf, R. \& Nakane, M., 1997. O que há de novo no Reino? Teoria e Debate, 35. Disponível em: http://www.teoriaedebate.org.br/materias/internacional/o-que-ha-de-novo-no-reino?page=full. Acesso em 25 out. 2013.

Cohn, A. \& Fonseca, A., 2004. O Programa Bolsa-Família e a questão social. Teoria e Debate, 57, pp.1-5.

Diniz, E., 2013. Desenvolvimento e Estado desenvolvimentista: tensões e desafios da construção de um novo modelo para o Brasil do século XXI. Revista Sociologia e Politica, 21(47), pp.9-20. DOI: 10.1590/S0104-44782013000300002

Draibe, S. 2003. A política social no período FHC e o sistema de proteção social. Tempo Social, 15(2), pp.64-101. DOI: 10.1590/S0103-20702003000200004

Fajnzylber, F., 1983. La industrialización trunca de América Latina. México: Editorial Nueva Imagen.

Faria, V. \& Graeff, E., 2000. Preparando o Brasil para o século XXI. Digit.

Fernandes, F., 1966. Educação e sociedade no Brasil. São Paulo: Edusp. 1975. Universidade brasileira: reforma ou revolução?São Paulo: Alfa-Ômega. , 1989. O desafio educacional. São Paulo: Cortez.

Filgueras, L., 2006. História do Plano Real. $3^{\mathrm{a}}$ ed. São Paulo: Boitempo Editorial.

Filgueiras, L. \& Gonçalves, R., 2007. A Economia Política do Governo Lula. Rio de Janeiro: Contraponto.

Fiori, J.L.; Medeiros, C. \& Serrano, F., 2008. O mito do colapso do poder americano. São Paulo: Record.

Garcia, M.A., 2006. Os horizontes do governo e do PT. Revista Teoria e Debate, 68.

Gonçalves, R., 2010. Análise comparativa do governo Lula - Resultados e Metodologia. In P. Passarinho, ed. Governo Lula: 2003-10. Aparência e Essência. Rio de Janeiro: Contraponto.

Goulart, J.O., 2013. Processo constituinte e arranjo federativo. Lua Nova, 88, pp.185-215. DOI: 10.1590/S0102-64452013000100007

Hall, P., 1986. Governing the Economy: The Politics of State Intervention in Britain and France. Oxford: Oxford University Press.

Hall, P. \& Taylor, R., 2003. As três versões do neo-institucionalismo. Lua Nova, 58, pp.193-223. DOI: $10.1590 /$ S0102-64452003000100010

Lafer, C. \& Fonseca Jr., G. Questões para a democracia no Contexto Internacional das polaridades indefinidas (Notas analíticas e algumas sugestões). In G. Fonseca Jr., \& S. Castro, eds. Temas de Política Externa Brasileira II. V. I. São Paulo: Paz e Terra.

Linz, J. \& Stepan, A., 1996. Problems of Democratic Transitions and Consolidation. Southern Europe, South America, and Post-Communist Europe. Baltimore: The Johns Hopkins University Press.

Lula da Silva, L.I., 2002. Carta ao povo brasileiro. Disponível em: http://www.iisg.nl/collections/carta_ao_povo_brasileiro.pdf. Acesso em 28 nov. 2013.

Mendonça de Barros, L.C. \& Pereira M.P., 2006. A força de Lula. Digit.

Mourão, J.O.F., 1994. A integração competitiva e o Planejamento no sistema BNDES. Revista do BNDES, 1(2), pp.3-26.

Novelli, M., 2007a. Inflação e desinflação: coalizões, conflitos e instituições no Brasil e em outros países. Tese de Doutorado. Campinas: Universidade Estadual de Campinas. , 2007b. A continuidade da política macroeconômica entre o governo Cardoso e o governo Lula: uma abordagem sociopolítica. Digit. 
Oliveira, G. \& Turola, F., 2003. Política econômica do segundo governo FHC. Tempo Social, 15(2), pp.195-217. DOI: 10.1590/S0103-20702003000200008

Paulani, L., 2008. Brasil Delivery. São Paulo: Boitempo.

Paulino, L.A., 2010. O Plano Real e os dois governos de Fernando Henrique Cardoso (1995-1998/1999-2002). In M.C. Pires, ed. Economia brasileira: da colônia ao governo Lula. São Paulo: Saraiva.

Pilatti, A., 2008. A Constituinte de 1987-1988: progressistas, conservadores, ordem econômica e regras do jogo. Rio de Janeiro: Lumen Juris.

Pinheiro, A. \& Giambiagi, F., 2006. Rompendo o marasmo: a retomada do desenvolvimento no Brasil. Rio de Janeiro: Elsevier.

Pochmann, M. 2010. Estrutura social no Brasil: mudanças recentes. Serviço Social \& Sociedade, 104, pp. 637-649. DOI: $10.1590 / \mathrm{S} 0101-66282010000400004$

Rocha, A.S., 2013. Genealogia da Constituinte: do autoritarismo à democratização. Lua Nova, 88, pp.29-87. DOI: 10.1590/S0102-64452013000100004

Rodrigues, L.M., 2006. Mudanças na Classe Política Brasileira. São Paulo: Publifolha.

Sallum Jr., B., 1996. Labirintos: dos generais à Nova República. São Paulo: Hucitec. 1999. O Brasil sob Cardoso - neoliberalismo e desenvolvimentismo. Tempo Social, 11(2), pp.23-47. DOI: 10.1590/S0103-20701999000200003

Sallum Jr., B. 2003. Metamorfoses do Estado brasileiro no final do século XX. Revista Brasileira de Ciências Sociais, 18(52), pp.35-54. DOI: 10.1590/S0102-69092003000200003

Sallum Jr., B. \& Kugelmas, E., 2005. O modo Lula de governar. In B. Sallum Jr., ed. Brasil e Argentina hoje: economia e política. Bauru: Edusc.

Santos, W.G., 1979. Cidadania e Justiça. Rio de Janeiro: Campus.

Singer, A., 2012. Os sentidos do lulismo: reforma gradual e pacto conservador. São Paulo: Companhia das Letras.

Velasco e Cruz, S., 2011. O segredo de combinar continuidade e mudança. Revista Faac, 1(2), pp.135-140.

Vigevani, T. \& Cepaluni, G., 2007. A política externa de Lula da Silva:a estratégia da autonomia pela diversificação. Contexto Internacional, 29(2), pp.273-335. DOI: 10.1590/S0102-85292007000200002

Vigevani, T.; Oliveira, M. \& Cintra, R., 2003. Política externa no período FHC. A busca da autonomia pela integração. Tempo Social, 15(2), pp.31-61. DOI: 10.1590/S0103-20702003000200003

\section{Artigos em jornais}

Goy, L.; Salvador, F. \& Nagakawa, F., 2008. Estatais criam alternativa para as PPPs. O Estado de S. Paulo, 23 jun., p.B5.

Safatle, C., 2008. Estatais, a nova onda. Valor, 13 jul., p.A2.

\section{Outras fontes}

University of Groningen, 2013. The Maddison Project. Disponível em http://www.ggdc.net/maddison/maddison-project/home.htm. Acesso em: 2 nov. 2016. 


\title{
The Brazilian Contemporaneous State: Economics Liberalization, Politics and Society in the Governments
} Lula and FHC

\begin{abstract}
The article identifies the features of the contemporary form of the Brazilian state - in force since 1995 - focusing its relations with the economic sphere and its policies against social inequality. It characterizes the ideas that guided the governing elites, the way the Brazilian foreign policy was redefined after the Cold War, the economic and social policies between 1995 and 2010. The central hypothesis is that there is a new form of State in Brazil since 1995 and that the variations between the different governments are part of the same story. The article opposes to the current characterization of the FHC and Lula governments as having followed a neoliberal policy. For this, it seeks to identify the policy that guided the two periods of government. It shows that it was liberalizing but moderate in regard to state intervention in the economy - merging policies guided by neoliberal and liberal-developmentalist ideas. Although there is enough continuity in government policies regarding the economy, the article attempts to show that the Lula period had a very important role in the stabilization of the state and even in the capitalist order. Indeed, the incorporation of union leaders, social movements and, in general, leftists to the State management, the extension of social protection to the poor and miserable and the creation of channels to facilitate the upward mobility of lower middle class strengthened the accession to the capitalist order and political stability, complementing the stabilizing effects of democratic rules and currency stability already recognized in the literature.
\end{abstract}

KEYWORDS: State; liberalization; social policy; neoliberalism; development.

This is an Open Access article distributed under the terms of the Creative Commons Attribution Non-Commercial License which permits unrestricted non-commercial use, distribution, and reproduction in any medium provided the original work is properly cited. 